thrombosis：CAT）は，がんの増殖や転移に関 与し発症し，がん治療に合併することも多く， 発症を予測した早期診断が重要である. CAT 発症には, がんが分泌する組織因子やがんの増 殖に伴う低酸素状態や炎症反応と共に, 白血球, 血管内皮細胞まで巻き込んだ複合的な機序が考 えられている。臨床的にも, 手術による長期卧 床, 脱水, 輸血, がんに伴う凝固能の立進状態, 放射線療法やがん治療薬に伴う内皮障害等がん 特有の病態が大きく関与している. さらに, 静 脈血栓塞栓のみならず, 動脈血栓塞栓症や播種
性血管内凝固症候群 (disseminated intravascular coagulation：DIC) 等多様な病態をとること から, 非がん症例における血栓症とは分けて対 応する．近年のゲノム医療の進歩に伴う精密医 療に基づくがん治療の進歩は，がん治療の長期 化やがんサバイバーの増加と共に出現する心不 全やCAT等の心毒性を中心とした晚期合併症が 問題となっている. 今後, さらに複雑化するが ん診療において，がん治療の適正化と長期予後 の改善を図るために, 疾病発症二次予防等の面 からも腫瘍循環器医の役割が期待されている.

\title{
16. 感染性心內膜炎の診断
}

\section{埼玉医科大学国際医療センター感染症科・感染制御科 光武耕太郎}

感染性心内膜炎は，心内膜（弁膜）を主座と する重症感染症である. 感染巣は心蔵にあるに もかかわらず，診断において重要なポイントで ある感染蔵器を推定させる症状にそしいことが 診断を難しくしており, 患者の 3 分の 1 は, 診 断までに 1 力月以上を要している. 感染性心内 膜炎は，敗血症を来たす代表的疾患であるが， viridans group streptococcusの場合, 多くは亜急 性の経過をとり, 感染症よりむしろ膠原病や悪 性疾患との鑑別を要して容易に診断に至らない ことがある。また，発熱や炎症マーカーの上昇 は非特異的であり，塞栓症による症状が目立つ と, 元々の感染臓器へ意識はさらに向きにくく なる，常に“まず感染性心内膜炎を鑑別に挙げ る”ことが重要であるとされる理由である．診 断においては, 血液培養と心エコー眓検査が最 も重要であるが, septicな患者で血液培養提出は
一般的に行われても, non-septicな臨床経過をと る場合は提出されないことが多い。また，血液 培養提出前の抗菌薬投与は, 検出率を著しく低 下させる。心エコー図検査も，本症を鑑別に挙 げなければ積極的には施行されないであろう.

Osler痛斑（結節）やJaneway病変のような特徴 的な皮膚粘膜所見は本症の診断において有用で あるが，出現頻度は数\%にとどまり，ベテラン の臨床医でも目にする機会は少ない，本症の診 療においては，国内外の診療ガイドラインが参 考になるが，新しいガイドラインでは，人工弁 における診断において,心エコー図に加えてPET/ CT (positron emission tomography/computed tomography）等の画像検査の有用性も報告され ている. 本講演では, 感染性心内膜炎の診断に ついて概説する. 